\title{
Architecture of the landform and settlements identities. Cycle-routes as new linear public spaces
} Chiara Occelli, Riccardo Palma

Polytechnic of Turin, Italy

Department of Architecture and Design

chiara.occelli@polito.it | riccardo.palma@polito.it

\begin{abstract}
One of the contemporary problems of dwelling concerns a threat to the interrelationship between settlements and geomorphology. We think that one of the most important peculiarities of public space is the power to represent these relations by means of architecture. Good quality architecture in public spaces would allow inhabitants to be a part of the places and territories in which they live. In the context of these problems, cycle-routes could play an important role, as a new kind of linear public space. They could become "geographical architecture" (Occelli \& Palma, 2008).
\end{abstract}

Keywords: landform; cycle-routes; infrastructures; identity; architecture; geography.

\section{To cite this article:}

Occelli, C., Palma R. (2017). Architecture of the landform and settlements identities. Cycle-routes as new linear public spaces. The Journal of Public Space, 2(2), 63-74. DOI: 10.5204/jps.v2i2.93

This article has been peer-reviewed and accepted for publication in The Journal of Public Space.

Please see the Editorial Policies under the 'About' section of the journal website for further information.

This work is licensed under a Creative Commons Attribution - Non Commercial 4.0

International License - https://creativecommons.org/licenses/by-nc/4.0/ 


\section{Introduction}

One of the most significant contemporary difficulties concerning dwelling concerns the threat to the relations between architecture and geomorphology. It is a serious threat because landform represents the main layer on which settlements are founded. Indeed, inhabitants' identities largely depended on this relation.

In history, public space represented this relation by means of its architectonic features, and the architecture of public spaces allowed inhabitants to be apart of the places and territories in which they lived.

Nowadays this relation is at risk of being eliminated because the architecture of public space is becoming more and more indifferent towards landform. Our research aims to study the relationships between the architecture of cycle-routes, settlements and landform. Indeed, in this problematic context, cycle-routes could play a strategic role as a new kind of linear public space. Our first hypothesis is that cycle-routes could become 'geographical architectures', i.e. linear public spaces able to represent the geographical identity of our settlements. The second hypothesis is that, if cycle-routes run along infrastructures like canals, railways, etc., they can take advantage of the deep relationships that infrastructures have with landform.

\section{2. 'Representation spaces' and settlement identities}

"One of the schizophrenic aspects of contemporary architecture is ... the renunciation of the relation with the ground as antropogeography and its history of settlement systems ... the refusal of the architectonic relationship with the ground and its reduction to neutral support without any mediation, corresponds well to the denial of any relations with history and geography" (Gregotti, 2010, p. 43)

In The Production of Space Henry Lefebvre outlines the distinction between the following three concepts: "spatial practice, which embraces production and reproduction, and the particular locations and special sets characteristic of each social formation ...

Representations of space, which are tied to the relations of production and to the 'order', which those relations impose ... Representation spaces, embodying complex symbolism, sometimes coded, sometimes not ..." (Lefevbre, I991, p. 33).

In contemporary times, a need for communities to share public spaces has arisen. These spaces should represent the identities of the local communities despite the complexity and the layered structure of contemporary territories. In fact, every space is lived differently by different users, communities or groups, but geographic features - the landforms - constitute the layer on which all the other layers stand. Therefore, a very important facet of inhabitants' identities is founded on landform.

Accordingly, public spaces are not to be considered as a priori entities but instead as being the result of a project that makes them architectonic representations of the landform. If public spaces represent landform, they can become 'representation spaces', according to Lefebvre. These kinds of spaces make the territory intelligible and liveable, because they provide inhabitants with an architectonic reproduction of the territory in which they live. Therefore, in order to design public spaces, it is necessary to recognise the landform and represent it faithfully in the architecture produced by the project.

Urban history underlines that such a re-appropriation of landform produces a refoundation. Indeed, to found means to perform a new description of existing place. For instance, the foundation of Rome appears to be - as recent archaeological studies confirm 
- a new distribution of the previous social and urban spaces in the same location, by means of a series of architectonic facts (events? or processes?) that had the role of creating 'representation spaces'.

According to studies by Andrea Carandini, Romulus' project consisted of adding one monumental and representative layer over previously sprawled villages. A new town centre was realised after the birth of the settlement (Carandini, 1997). This foundation was political and spatial at the same time: the configuration of the Palatino-CampidoglioForo complex as the new centre of the archaic Rome provided Roman people with a new representation of the landform of the site of Rome. The platform of the Roman Forum was the architectonic representation of the previous marshes that occupied the valley between Palatine Hill and Capitolium Hill. The construction of the defensive and sacral wall around Palatine - i.e. the realisation of the Roma Quadrata (Squared Rome) represented the architectonic description of the hill itself. However, above all, the cruciform scheme of the Auguratio - that returns in the military scheme of the castrum describes the cruciform figure of the site of Rome, formed by the two channels of the Tiber and their prolongations in the Murcia Valley and Velabrum Valley.

Like archaic Rome, contemporary settlements are often described as being un-founded places, both by many scholars and the public. However, like Rome, these territories could be re-founded if a new description can be given to their public spaces. Indeed, as the foundation of Rome clarifies, foundation is a project that can be repeated many times. In this sense, our settlements could be described as places waiting to be founded rather than places with no foundation. That means creating 'representation spaces', i.e. designing public space architecture (made of surfaces, paths, buildings, vegetation, etc.) able to represent a geographic reality: the inhabited territory, with its stratifications made of anthropic and natural dimensions.

It is, therefore, necessary to think about 'geographical architectures' and their role in the construction of contemporary public spaces.

\section{3. 'Geographical architectures' and cartographic devices}

Rome's public space was not built on the seven hills but on the marshes in the valleys below. There is an intriguing monument in the middle of the Roman Forum, called Lacus Curtius. It is a pit in the floor of one of the most famous public spaces in the ancient city. According to legend, a young soldier on horseback called Marcus Curtius sacrificed himself to placate the Gods and save the city, by throwing himself and his horse into a chasm, which had suddenly appeared in the ground after a storm. Ever since that day the hole was called Lacus ('Lake') Curtius and it was venerated until the fall of the Empire. The Lacus is a small but disturbing place, a hole that linked the ground of the city with the Gods of the underworld. Revered for centuries, the Lake was an incessant reminder to Roman people of the presence of the ancestral marshes upon which they built the first public space of the city.

The Forum was the first true example of Roman public architecture, built before the construction of the other edifices - the temples, the basiliche, the palaces and the domus. The imposing monument is in fact a simple built surface that filled the Velabro Valley and both shrouded and recalled the waters of the marshes. Archaeological surveys indicate that the valley was filled for the first time around the period in which the city was founded - the 'Romulean Project' as it is called by Andrea Carandini - dates back to the second half of the 8th century B.C. (Carandini, 1997) (fig. I). 


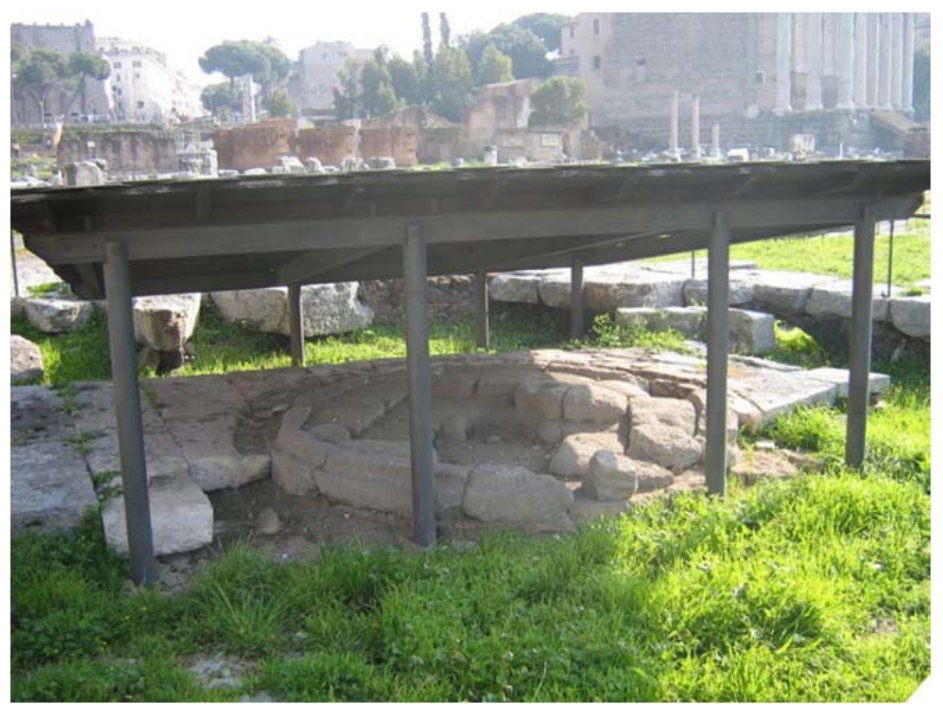

Figure I. View of Foro Romano and the Lacus Curtius. Source: Photography by the authors.

This transformation of landform to architecture was a real transfiguration, i.e. a 'changing state', from water to stone. A stone surface substituted and, at the same time, represented the image of the water: the abstract perfect image of the undisturbed still water was substituted by a solid architectural surface. The floor of the Forum became the architectural translation of the unforgettable ancestral image of the primitive marshes. Before becoming walkable ground on which social and political relationships could be developed, the Forum worked as a kind of map that represented the original waters. Together with Lacus Curtius, a number of small monuments were connected to the waters, like Umbilicus Mundi and Lapis Niger, which constituted a system of hole-like architectures inscribed within the thickness of the Forum slab. Paradoxically they represent both the pre-existing primitive valley covered by marshes and the obliteration of the valley (Farinelli, 2009). As the Forum replaces the ground by means of its architectural representation, it becomes a 'geographical architecture': a public architecture that produces a 'foundational description' (Magnaghi, 2005) for the whole community. This description allows citizens to assert their identity as inhabitants of a specific territory, characterised by a specific geography (Occelli \& Palma, 2009). The floor of the Forum also represents a series of boundaries: the boundary between the natural marshes and the buildings that have been constructed upon it; the boundary (but also the bridge) between the unsafe marshy valley and the stable hill slopes. This representation of the waters does not imply a re-discovery of natural and uncontaminated origins beneath artificial architecture. Ever since humankind began to observe it, the Earth has been seen as an architectural entity. The role of spaces like the Roman Forum is to keep the relationship between Earth and Architecture open and unsolved - 'indiscernible', in Jacques Derrida's words. One of the purposes of public spaces in contemporary territorialised cities is to perform the spectacle of this indiscernible condition that embraces Water, Earth and Architecture (Pizzigoni, 20I I).

Therefore, in order to design public space, we have to reverse the logic of classic representation: the space, the canonical object of the 'representation', becomes the agent of representation. The Forum is not only an architectonic space but it is also a solid map 
and it opens up the possibility of studying the design of public spaces as representations of landform.

The fact that a designed space represents another space, another territorial or geographic space, is usual for architecture. This representation is often based on the relationships between architectural design and cartographic representation. In their study on architectural design theory, Giancarlo Motta and Antonia Pizzigoni describe cartography as one of the 'machines' which produces architecture (Motta \& Pizzigoni, 2006). In architectural design, the solution to the problems of a site is always a cartographic figure as the solution is found on the map and it is the product of cartographic devices. This is the way in which the cartographic 'machine' works and involves the whole production of the architecture: sometimes the building itself works like a map. Therefore, scaling, layering, use of grids, disposition of the elements of the project in a form of a cartographic legend, are at the same time cartographic devices and techniques of architectural composition (Palma, 2002). Refer, for example, to all those projects that deal with the problem of the representation of territory: the problem is often solved by means of the cartographic dimension of architectural design as it happens, for instance in Peter Eisenman's projects, such as the California State University Museum project. This tradition gathers theatres of memory and landscape gardens, and it is based on the capability of architecture to represent geographic and imaginary spaces simultaneously (Halbwacs, 194I; Rossi, 1966).

\section{Infrastructures and 'geographical architectures'}

The architecture of linear infrastructures like irrigation canals, aqueducts, roads or railways overlaps the landform with its own utilitarian logic. Paradoxically, we are uncertain as to whether infrastructure exalts landform similarly as landform exalts infrastructure (Ferlenga, Biraghi \& Albrecht, 20I2).

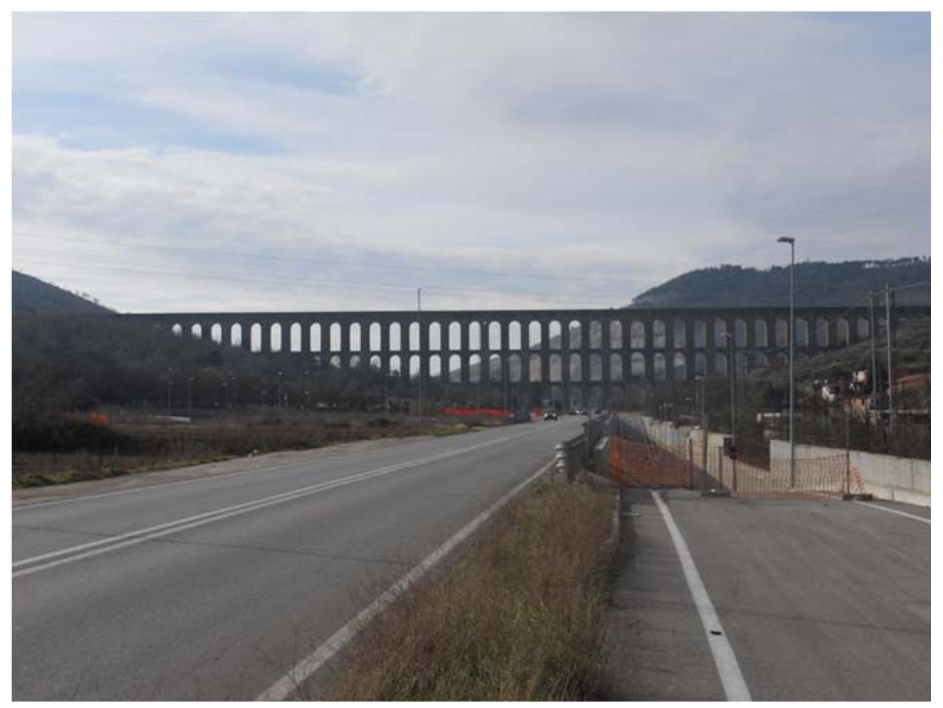

Figure 2. The Maddaloni aqueduct by Luigi Vanvitelli. Source: Photography by the authors.

For instance, the aqueduct of Maddaloni designed by Luigi Vanvitelli to carry water to the Reggia of Caserta, produces a spectacular representation of the valley in an architectonic 
form that reveals the topographical section: the orders of arches of the aqueduct fill the void between the slopes underlining the monumental shape of the valley that had never been pointed out before. The performance required from the aqueduct is to transport water for many kilometres using slight, incremental inclinations. These are not considered at the architectural scale, as to be so requires a particular fixity, or permanence, of architecture. As a fixed architectural element is a constant feature of all infrastructures, infrastructures can easily become 'geographical architectures'.

One paradigmatic example of a fixed architectural element is San Francisco's urban grid. In San Francisco, despite the fact that the ground is very hilly, the grid layout of the roads is rigidly ruled by orthogonality. At all the points where the conflict between geomorphology and infrastructure becomes difficult to solve, we find a monumental piece of architecture that exalts the landform. The conflicts were overcome by a series of architectural solutions that were applied where the rigid application of the grid was impossible because of the angle of ascent of the new roads. The solutions - huge stairways, mighty embankments, duplication of parallel roads at different levels - solve the contradiction between geometry of the grid and altimetry of the ground and in addition serve as a monumental interpretation of the landform (Lipsky, 1999). Between the architecture of infrastructures and the geography of places there is no imitation but there is a mutual becoming that is based on a molecular process: architecture replaces landform but in some way landform remains a part of architecture. It is only a matter of changing state (Pizzigoni, 20I I).

\section{Cycle-routes as new linear public spaces}

Nowadays the ancestral relation between dwelling and landform is often denied by the architecture of settlements, which are ever more extraneous regarding geography. For instance, this denial brings very dramatic results when rivers flood. However, it seems that architectural and urban design have left this problem out: in particular public spaces have lost their role as 'representation spaces' of the landform. More and more often they become abstract, generic spaces enclosed in shopping centres.

Our research hypothesis concerns the role of cycle-routes in order to reconcile this relation. In fact, wherever a cycle-route is associated with an existent infrastructure, the spectacular and architectonic representation of the landform becomes a feature of the bicycle path. It is possible to claim that cycle-routes are not only important for sustainable tourism and development but they could also become new kinds of linear and interconnected public spaces, highly important for the identities of settlements themselves. Indeed, cycle-routes can represent new kinds of 'representation spaces' along which inhabitants can recognise the geography of the places where they live.

Thus, cycle-routes aligned side by side with existent infrastructures could play the role of 'geographical architecture', linking people to landform and in turn to their geographic identity. Sometimes in the history of settlements, public space was a linear space: for instance, we can think about the merchant and pilgrim paths, the Sacri Monti, which are sacred Italian paths that represent Jesus Christ's passion through a series of chapels, and so on. Cycle-routes exhibit many features of traditional linear public space. In particular, cycle-routes are used by different kinds of people: tourist cyclists, runners, walkers, but also people who travel to work by bicycle. The simultaneous presence of these different kinds of people, the polarisation and concentration of facilities and the randomness of events that could happen along the path, are all features of public space. 
Our research is developed through theoretical work and architectural projects, that attempt to answer some questions such as: what kind of space are the cycle-routes? Can settlements connected by this public space be redesigned on the bases of the new relationships created by cycle-routes? Another set of questions concerns the relationship between cycle-routes and geography: can cycle-routes be designed as 'representation spaces'? Can they represent an identification value for inhabitants, who are arguably less equipped to attribute meaning to places in today's world? Can cycle-routes be designed so that they could tell their users about the landform?

We attempted to answer these questions through developing a set of projects. Two of them are described and discussed below.

\section{Project I: Cavour Canal Cycle-Ruote}

The Cavour Canal (I86I-1865) was the first great infrastructure built after the unification of Italy. The Canal brings water from the Po River to the Ticino River, allowing the irrigation of a wide portion of the Padania plain, characterised by rice cultivation. The Canal is 82 kilometres long and provided service paths. It crosses rivers, torrents and others pre-existing canals, and runs near cities and rural settlements with important historical and cultural heritage. It flows into the Ticino River where it meets the medieval system of the Naviglio Grande Canal, which connects Lake Maggiore with Milan. Over the last few years, the Naviglio Grande Canal has become a cycle-route used intensively by tourists and the local population.

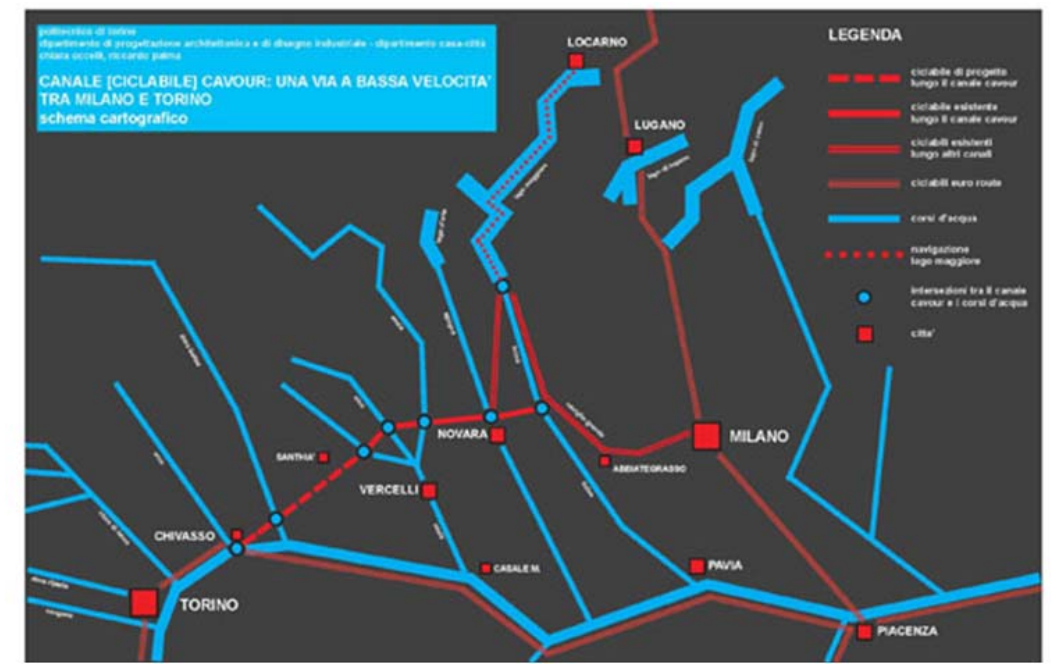

Figure 3. The connections between the cycle-route of the Cavour Canal and the European context. Source: Occelli, Palma and Sassone 2012.

The Cavour Canal, cutting the plain with minimum gradient, represents a section line on which the hydrographic system of the Piedmont side of the Alps is projected. Indeed, each intersection is marked by monumental hydraulic works that aim to solve the crossing and/or the mixing of waters. In this way, each intersection is also an architectonic representation of the landform and cycling along the canal becomes a dynamic experience of travelling through histories, cultures and the geomorphology of the territory. 
Our project also finds its reasoning in the strategic importance of the Cavour Canal in the European network of cycle-routes. In fact, the Canal could offer a solution to the intersection of Route 7 from Cape North to La Valletta with Route 8 from Cadiz to Athens. It allows both a connection with France and Milan, taking advantage of the route along Lake Maggiore, and the historical path of the Naviglio Grande. At a national scale, this path offers a new and important connection between Turin and Milan that can assume compensation value in terms of low-velocity travel for the recent realisation of the highvelocity railway.

This research, commissioned by the Parco del Po tratto torinese at the Department of Architecture and Design at the Polytechnic of Turin, concerns the role of the Canal on multiple levels: the touristic development of this territory on a European scale, that is not yet valorised; the improvement of the quality of the sustainable mobility system in Piedmont and Lombardy; the connection with the theme of Expo 2015 in Milan, "Feed the Planet", because of the importance of the Canal in rice cultivation; the potential role of the Canal as a distribution element for a system of public spaces that will be able to connect the settlements it traverses; the development of a 'geographical architecture' 82 kilometres long.

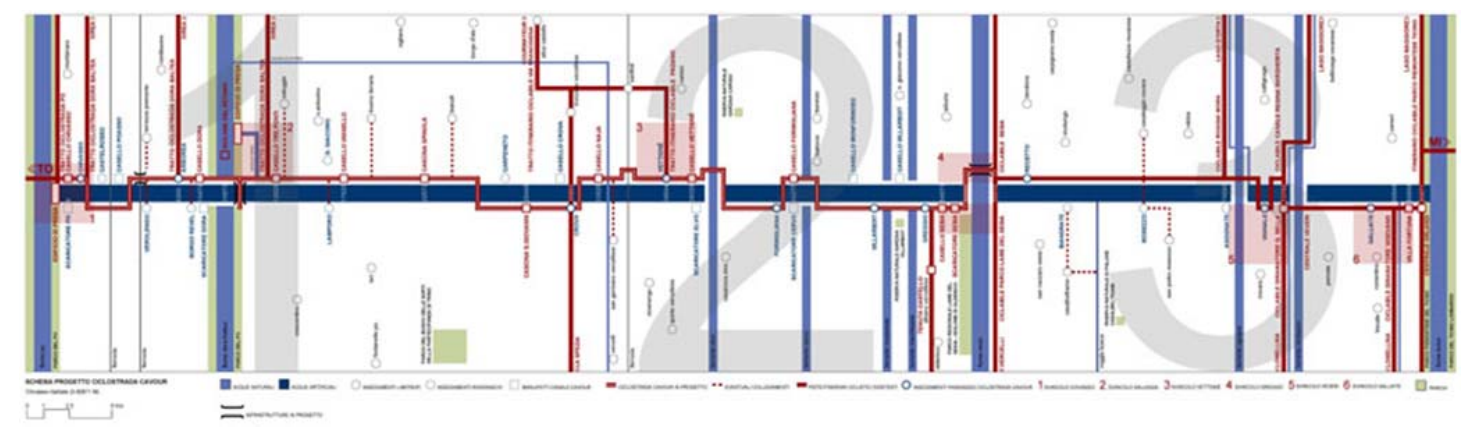

Figure 4. Functional diagram of the cycle-route of the Cavour Canal. The scheme shows the intersections with the other cycle-routes and the hydrographic elements. The project fixes the main public spaces in these intersection points. Source: Occelli, Palma and Sassone 2012.

The developed guidelines of the project attempt to match the problem of conservation and valorisation of the historical and architectural features of the Canal with the requirement to maintain the hydraulic system's efficiency. The project works by superposing not deleting: in order to have a correct and non-mimetic dialogue between the pre-existing and the new interventions, the project uses the architectural figures that are expressed by the different representations of the Canal. Thus, for instance, the new infrastructures like footbridges or protected paths have the same section of the monumental siphons, which allow the Canal to pass under the rivers (Occelli, Palma and Sassone, 2012).

Moreover, the project aims to play an important role not only in restoring the Cavour Canal but also in enhancing the territory that this monumental infrastructure has generated. The agrarian landscape, an exemplary human construction, is at the centre of a project based on an element that seems weak, the cycle-route. Indeed, the experience of cycling along the Canal allows travellers to intersect all the geographical elements that form the territory. Indeed, in our study the Canal has been considered as a kind of 'geographical theatre' able to represent the entire geography of the eastern part of 
Piedmont. The whole complex of monumental intersections - bridges and siphons between the Canal and the hydrographical system represents an 'architectural section' of the territory crossed by the Canal.

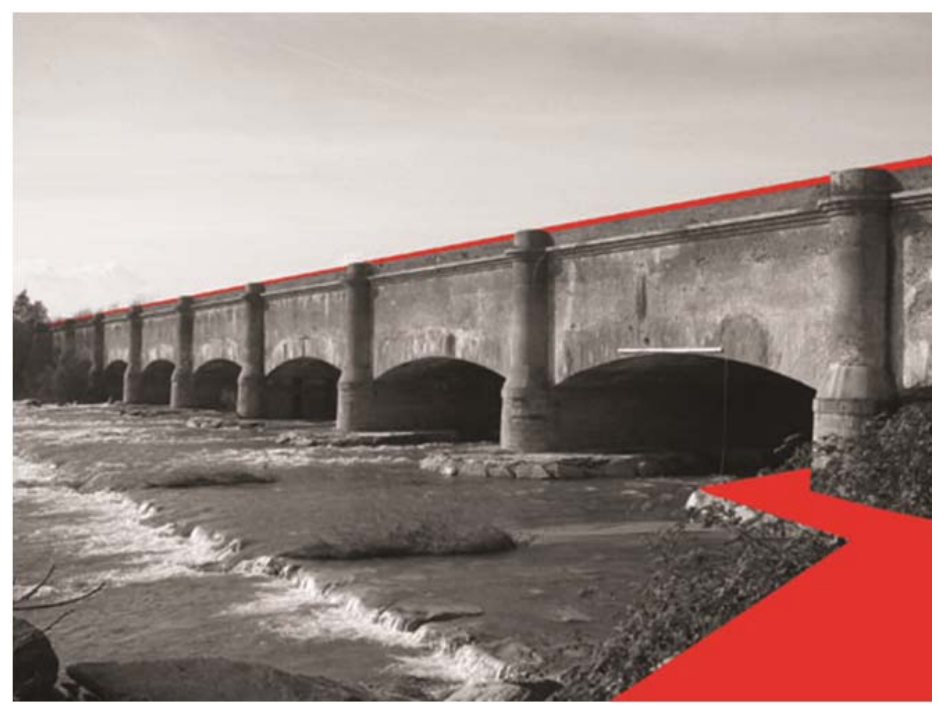

Figure 5. View of the cycle-route on a bridge-canal. Source: Occelli, Palma and Sassone, 2012.

This project aims to restore international fame to the Cavour Canal, the kind of international fame it had when its monumental architecture reached a mythical dimension. In fact, during and after its realisation the Canal become famous among engineers all over the world, for example, among the US engineers of the Sacramento River Canal (Occelli, Palma and Sassone, 20I2).

\section{Project 2: services pavilions along the cycle-route of Lake Varese}

The bicycle path of Lake Varese in northern Lombardy is already successful and much used by inhabitants. For this reason, our project, developed in the context of an architectural competition, does not concern the path itself but attempts to add new layers of meaning to the existing cycle-route. The project envisages the whole bicycle path as a new linear public space.

The first layer is symbolic and concerns the identities of the settlements: the project foresees a path articulated in fourteen pavilions, like the fourteen chapels of the Sacro Monte in Varese. This analogy solves two different problems: the first is the path's lack of architectural unity; the second is the specificity of the places and the settlements, which share the Lake. Every pavilion is part of the whole path but in addition each one represents the identity of a single settlement by means of the variations in its architecture. Following this analogy, the fourteen pavilions are little buildings that provide services to cyclists and to people who walk along the path. The section of the buildings is always the same and is generated in analogy with the drawing of the section of the Sacro Monte chapels

The second layer of the project concerns the accessibility system to the Lake and the provision of services along the path. The project mobility scheme is composed of three concentric rings: the first is that of the Lake itself and of places along the coast that are 
accessible via tourist navigation; the second is that of the cycle-route itself; the third is that of the vehicular roads which surround the Lake.

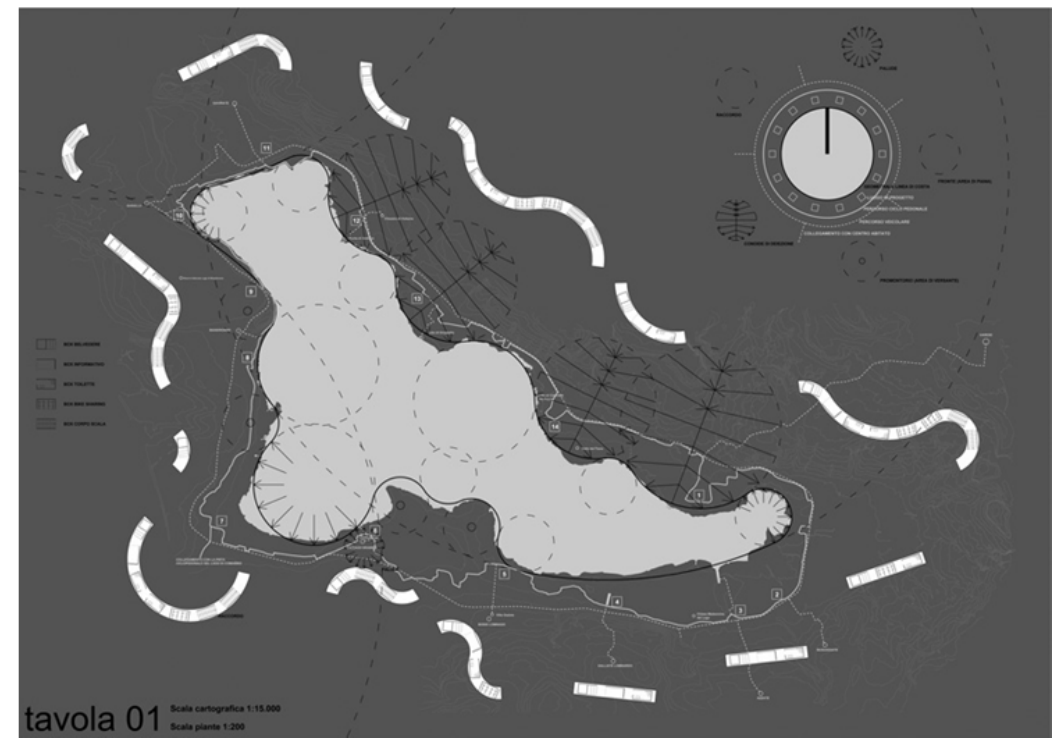

Figure 6. The cycle-route and landform: facilities buildings plan

Source: N. Besenval, C. Occelli, R. Palma, M. Sassone with D. Campolo, A. Dutto, Cycle-route project around Lake Varese, 2013

These three modes of travel around the Lake are crossed by the ancient paths that connect the existing settlements to the Lake. Therefore, the pavilions are placed at the intersections between the cycle-route and those paths. The plan of the pavilions - formed by a three-metre-wide double wall in which all services are placed - is drawn on the basis of the line that describes the geometry of the Lake coast. In this way, every building represents the portion of the coastline that belongs to a different settlement. In fact, this line is not only an abstract geometric representation of the cartographic shape of the coastline, but it also expresses the geomorphological features of the Lake. The different kinds of circumferences that compose the line describe: the sequence of alluvial fans, the headlands of the Lake's glacial basin and the low marshy coasts. Overall, the projected pavilions translate the geomorphology of the Lake into 'geographical architectures'. The third layer concerns the architecture of the single pavilion. The different services (information point, bicycle rental, panoramic point, place of rest, public facilities) are all placed in wooden boxes, which all have the same modular dimensions. The boxes are contained within a metallic structure covered by perforated sheets that allow a view of the inner boxes. This transparency uncovers a last figure that the project wants to exhibit: a figure of a stylised fish, design to appear as though a child had drawn it. In fact, each box corresponds to a part of this fish: the information point is the 'head', the panoramic point is the 'tail' and all the other boxes in-between are pieces of its 'body'. This zoomorphic allusion remembers both the religious symbolism related to Christ and, above all, the identity of the Lake that was once one of the most fish-rich Italian lakes. Although bicycle paths could be easily be perceived as being unimportant for the structuration of settlements, the bicycle path of Lake Varese takes on the meaning of a re-foundation, where it becomes a linear public space that assumes the role of 'geographical architecture'. 
In the great water-plaza constituted by the Lake, our project recognises a resemblance with the current centre of the city of Varese.

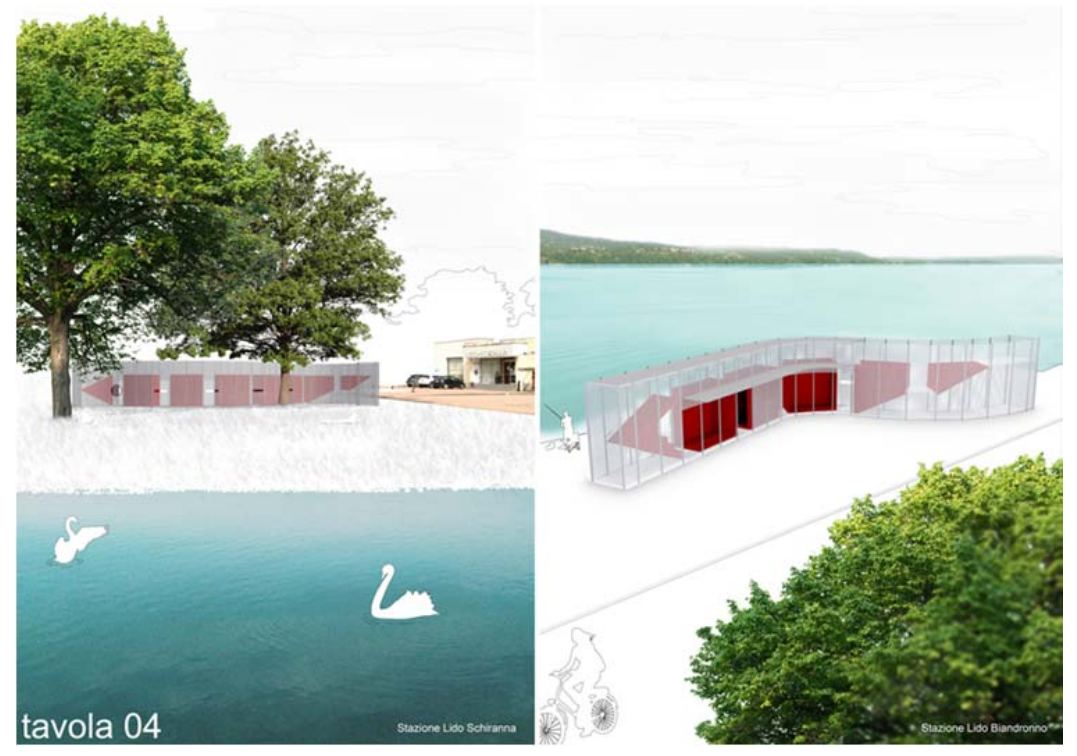

Figure 7. Views of service buildings along the cycle-route

Source: N. Besenval, C. Occelli, R. Palma, M. Sassone with D. Campolo, A. Dutto. Cycle-route project around Lake Varese, 2013

The centre was only built in the 20th century, around a system of boroughs called castellanze and until then it had been largely empty, characterised by the presence of water. In the same way our project transforms the Lake into a water architecture that the bicycle path and its pavilions embrace, represent and interpret as a single, archetypal, identitarian public space.

\section{Conclusion}

To sum up, the proposed hypothesis foresees that in the future the role of cycle-routes in tourism and in supporting mobility will increase in importance, together with the need for new kinds of public spaces, characterised by their linearity and capability to represent the landform. Therefore, nowadays cycle-routes represent an opportunity for inhabitants, in that they both enhance touristic development and elevate consciousness surrounding geographic features in their territories. The challenge for architects is to design cycloroutes as linear public spaces with a consciousness of their role as 'geographic architectures'. In this way, along all cycle-routes people will have an experience that could contain the potential to contribute to a re-foundation of their settlements. An experience based on the ancestral relationship between the architecture of public spaces and landform.

\section{Notes}

* Although the article should be considered the result of the common work and reflections of the two authors, Occelli takes primary responsibility for paragraphs I, 2, 3 and 4, Palma takes primary responsibility for paragraphs 5, 6 and 7 . 


\section{References}

Carandini, A. (1997). La nascita di Roma. Dèi, lari eroi e uomini all'alba di una civiltà. Torino: Einaudi. Farinelli, F. (2009). La crisi della ragione cartografica. Torino: Einaudi.

Ferlenga A., Biraghi M. \& Albrecht, B. (Eds.) (20I2). L'architettura del mondo. Infrastrutture, mobilità, nuovi paesaggi. Compositori: Bologna.

Gregotti, V. (2010). Tre forme di architettura mancata. Torino: Einaudi.

Halbwacs, M. (194I). La topographie légendaire des évangiles. Paris: Presses Universitaires de France.

Lefevbre, H. (199I). The production of space. Oxford: Blackwell Publishing (original work published 1964).

Lipsky, F. (1999), San Francisco, la grille sur les collines / the grid meets the hill. Paris: Parenthéses.

Motta, G. \& Pizzigoni, A. (2006). Les Machines du Projet - L'Horloge de Vitruve et autres écrits. Anthropos - Economica: Paris.

Occelli, C., Palma, R., \& Sassone, M. (2012). La ciclostrada del Canale Cavour. Cuneo: ArabaFenice.

Occelli, C. \& Palma, R. (2009). Architetture geografiche e invenzione architettonica del territorio. Restauro e progetto degli insediamenti rurali lungo il terrazzo fluviale del Po torinese. Architettura del Paesaggio, n. 20.

Occelli, C. \& Palma R. (2008). Architetture geografiche. Memoria dell'antico e rappresentazione del territorio nel progetto dell'Ecomuseo. In Marotta, A. (Ed.), Qualità dell'architettura, qualità della vita. Torino: Celid.

Palma R. (2002). L'immaginario cartografico dell'architettura, Bergamo: Tecnograph.

Pizzigoni, A. (20I I). Il luogo: spazio cartografico e dispositivi di progetto. In Palma R. (Ed.), Motta, G. \& Pizzigoni, A., La Nuova Griglia Politecnica. Milano: Franco Angeli.

Pousin, F. (2005). Figures de la ville et construction des savoirs, Paris: CNRS Editions.

Rossi, A. (1966). L'architettura della città. Padova: Marsilio.

Terrenato, N. (1992). Ricostruzione topografica della valle tra Palatino e Velia. Bollettino di Archeologia, n. 16-17-18. 